\title{
УДК 378.147:376
}

\section{Лаптєва Марія Вікторівна}

кандидат педагогічних наук, докторант кафедри теорії і методики професійної освіти Харківський національний педагогічний університет імені Г. С. Сковороди, м. Харків, Україна mlapteva@ukr.net

\section{ІНСТРУМЕНТИ СТВОРЕННЯ СПЕЦІАЛІЗОВАНОГО ОСВІТНЬОГО СЕРЕДОВИЩА ДЛЯ НАВЧАННЯ ІНОЗЕМНИХ СТУДЕНТІВ У ВПНЗ УКРАЇНИ}

\begin{abstract}
Анотація. У статті зроблено аналіз інструментарію для створення сучасного освітнього середовища для адаптації іноземних студентів у навчальному процесі у вищих педагогічних навчальних закладах України. Розглянуто можливості використання різноманітних сервісів у практичній діяльності викладача для побудови освітнього простору з виходом на спільну діяльність слухачів з урахуванням специфіки навчальної аудиторії. Проаналізовано особливості навчання іноземної аудиторії. Запропоновано низку вільних у використанні сервісів, які вдало поєднують потужні і прості у використанні засоби для створення інтерактивних навчальних матеріалів, призначених для застосування в мережі Інтернет, у системах дистанційного навчання або іншому носії.
\end{abstract}

Ключові слова: освітнє середовище; інтерактивні навчальні матеріали; іноземні студенти.

\section{1. ВСТУП}

Експорт освітніх послуг — одна з найважливіших тенденцій розвитку сучасної освіти. Останнім часом спостерігається підвищення обсягу замовлення на підготовку в Україні педагогічних кадрів для країн, пріоритетними напрямами розвитку держав яких визнано і закріплено законодавчо розвиток освітньо-виховної системи. Наразі на перший план виступає задача підготовки педагогічних кадрів у галузі інформатичної освіти.

\section{Постановка проблеми.}

Нині організація навчально-виховного процесу неможлива без використання сучасних технологій навчання. Для оптимального вирішення освітніх завдань доцільно застосовувати в навчальному процесі IКТ, інтегруючи їх з іншими сучасними освітніми технологіями.

Аналіз основних досліджень і публікацій. Зародження нового освітнього середовища, найважливішими складниками якого стали інформаційні технології - це характерна риса сучасного розвитку освіти в Україні [2]. Проблемам створення інформаційного освітнього середовища присвячені дослідження таких учених, як В. Ю. Биков, Р. С. Гуревич, М. І. Жалдак, I. Г. Захарова, I. М. Кухаренко, Ю. І. Машбиць, С. С. Полат, С. О. Сисоєва, П В. Стефаненко та інші.

Не менш важливою складовою є електронні засоби навчального призначення: програмні засоби навчального призначення, електронні бази даних з відповідним наповненням (бібліотеки електронної наочності, електронні довідники і словники і т. ін.). Яскравим показником актуальності цього напрямку є те, що сьогодні у більшості технологічно розвинених країн існують спеціальні програми, які дають можливість створювати й упроваджувати у навчальний процес нові навчальні середовища [1].

Якщо звернутися до загального аналізу педагогічних середовищ, з'ясуємо, що сам термін «середовище» в педагогіці активно став вживатися з початку 1990-х рр., а його змістове наповнення неоднозначне. Існують різні підходи, відповідно до яких розрізняють інтелектуальне, соціальне, освітнє, виховне, тренажерне, інформаційне 
середовище. У цей же час почали активно розроблятися авторські розвивальні середовища, у тому числі комп'ютерні.

Ще кілька років тому викладачі переважно використовували Інтернет 3 метою пошуку інформаційних матеріалів для забезпечення навчального процесу, а сьогодні ясно позначена тенденція розвитку освітнього Інтернету: розробка власних ресурсів, створення електронних навчальних об'єктів. Безумовно, цьому сприяла зростаюча популярність сучасних веб-сервісів для створення, редагування і зберігання файлів. Розширення освітнього середовища припускає, що викладач сам ставатиме автором і розробником матеріалів для більш якісного навчання. Сучасна аудиторія вимагає сучасних методів спілкування і навчання. Особливо це важливо у спілкуванні 3 іноземною аудиторією [3]. Тому питання створення спеціального навчального середовища i використання його в процесі адаптації іноземних студентів на початковому етапі навчання i в подальшій практичній діяльності стає особливо актуальним.

Метою нашого дослідження $\epsilon$ аналіз можливостей використання різноманітних сервісів у практичній діяльності викладача для побудови свого освітнього простору 3 виходом на спільну діяльність слухачів з урахуванням специфіки навчальної аудиторії. Особливість навчання іноземної аудиторії полягає в тому, що результат самого навчання залежить від того, наскільки вдало вдається спроектувати методи і прийоми навчання під час використання сучасних засобів: дидактичні матеріали в електронному вигляді, адаптація матеріалів до рівня сприйняття за допомогою спеціальних засобів (словники, перекладачі), засоби дистанційної взаємодії та ін.

\section{2. РЕЗУЛЬТАТИ ДОСЛІДЖЕНЬ}

Коли мова йдеться про вдале поєднання потужного і простого у використанні засобу для створення інтерактивних навчальних матеріалів, призначених для застосування в мережі Інтернет, у системах дистанційного навчання, на компакт-диску або іншому носії, першим у списку досліджень з'являється сервіс CourseLab [4].

За допомогою CourseLab можна створювати і редагувати навчальний матеріал у середовищі WYSIWYG (What-You-See-Is-What-You-Get), що не вимагає додаткового знання мов програмування.

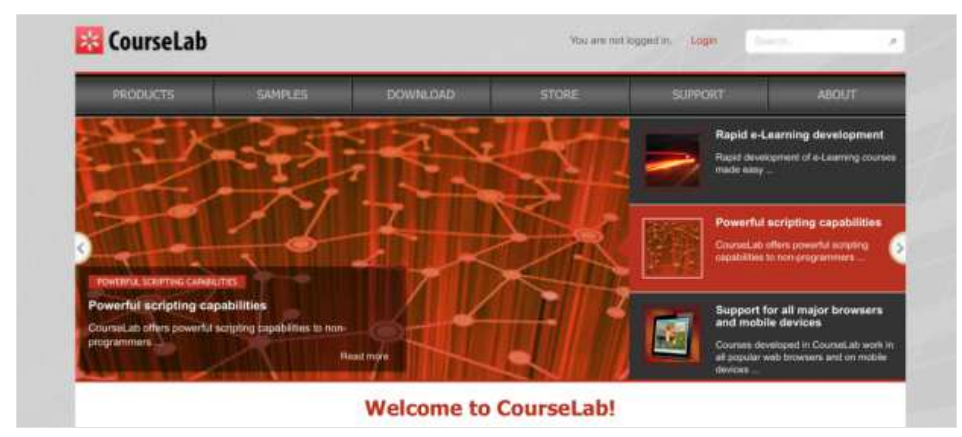

Puc. 1. Iнтерфейс сервісу CourseLab

\section{Особливості CourseLab:}

- не вимагає від автора знання мови HTML або будь-яких мов програмування;

- вбудовані засоби побудови тестів;

- об'єктний підхід дозволяє - як з дитячих кубиків - будувати навчальний матеріал практично будь-якої складності; 
- відкритий інтерфейс дозволяє легко розширювати бібліотеки об'єктів і шаблонів, у тому числі й за рахунок створених самим користувачем;

- імпорт презентацій з Microsoft PowerPoint;

- вбудовані механізми анімації об'єктів;

- можливість вставки в курси будь-якого Rich-media наповнення - Macromedia Flash, Shockwave, Java, відео в різних форматах і т. п.;

- прості механізми вставки і синхронізації звукового супроводу;

- можливість імпорту в навчальний матеріал презентацій з формату Microsoft® PowerPoint ${ }^{\circledR}$;

- вбудований механізм захоплення екранів, що дозволяє легко створювати симуляції роботи різних програмних продуктів;

- проста вбудована мова опису дій;

- досвідченому користувачеві редактор надає додаткові можливості через прямий JavaScript-доступ до властивостей об'єктів і функцій програвача курсів.

Галузі застосування:

- виготовлення електронних навчальних курсів;

- ознайомчі і ввідні матеріали;

- рольові ігри для формування професійних навичок;

- інтерактивні довідники;

- спеціальні тести й іспити;

- засоби опитування;

- on-line тренінги.

CourseLab містить набір готових шаблонів модулів. Для створення навчального модуля немає необхідності будувати свій шаблон - досить вибрати відповідний за дизайном шаблон 3 набору готових шаблонів. Якщо виникне необхідність, шаблон може бути змінений прямо в редакторі CourseLab для більш точної відповідності обраному автором стилю. Модифікований так шаблон може бути збережений i використовуватися згодом для створення нових модулів.

Бібліотека готових об'єктів. Для прискорення створення навчальних матеріалів у редакторі CourseLab вбудовано велику кількість готових до застосування складних об'єктів, що виконують різні функції - від різних способів показу тексту до складного тестування - i не потребують наразі ніякого програмування. Достатньо лише вибрати потрібний зовнішній вигляд об'єкта відповідно до дизайну модуля і заповнити його параметри. CourseLab дає можливість використовувати одного разу вставлений об'єкm багаторазово, включаючи і вимикаючи його показ спеціальними діями.

Цей сервіс дозволяє використовувати вже готові презентаціï у форматі PowerPoint: вони можуть легко і швидко бути імпортовані в навчальний модуль. За необхідності можна поправити імпортований матеріал вже в редакторі CourseLab.

Проста публікація навчальних курсів - це важлива характеристика даного сервісу: достатньо вказати параметри курсу і його навчальних модулів і вибрати тип публікації - усе інше (включаючи генерацію мета-файлів для подальшого імпорту в СДН ) CourseLab виконає автоматично.

Можливості використання різних форматів, які дані під час створення навчальних модулів обмежені тільки можливостями програми-браузера. CourseLab nidmpuмyє найбільш популярні формати даних. 


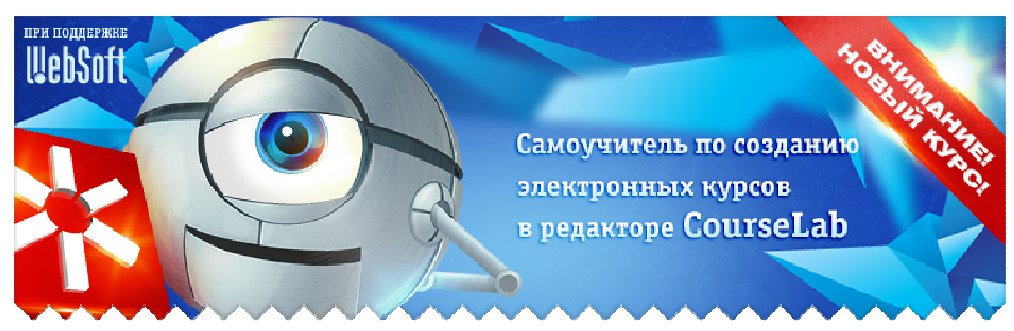

Pис. 2. Інтерфейс самоучителя CourseLab

Наступний сервіс, на який ми хотіли б звернути увагу, — це Smart Builder [6].

Smart Builder - це сервіс, що дозволяє створювати власні електронні освітні курси, не володіючи навичками програмування. Тут можливе використання різних медіа, ігрових елементів і т. д. У бібліотеці Smart Builder вже міститься велика кількість елементів від мультимедіа об'єктів до шаблонів сторінок.

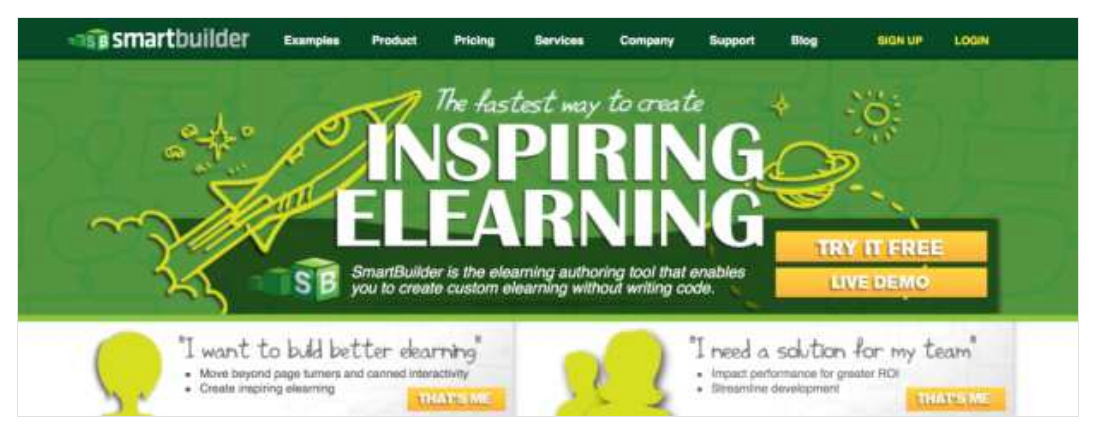

Puc. 3. Iнтерфейс сервісу Smart Builder

\section{Особливості Smart Builder:}

- не вимагає від автора знання мови HTML або будь-яких мов програмування;

- зручний засіб для побудови навчального матеріалу;

- наявність бібліотеки об' єктів;

- можливість використовувати готові шаблони;

- можливість створення візуального пояснення матеріалу на основі блок-схем;

- використання загальної змістовної бібліотеки.

Бібліотека об'єктів. Для прискорення створення навчальних матеріалів у редактор Smart Builder вбудовано велику кількість готових до застосування складних об'єктів, що є будівельним матеріалом і виконують різні функції. Бібліотека включає в себе: текст, зображення, аудіо, відео, форми, прапорець, перемикач, у спливаючому меню, точки доступу, введення тексту, перетягування, таймери і багато іншого.

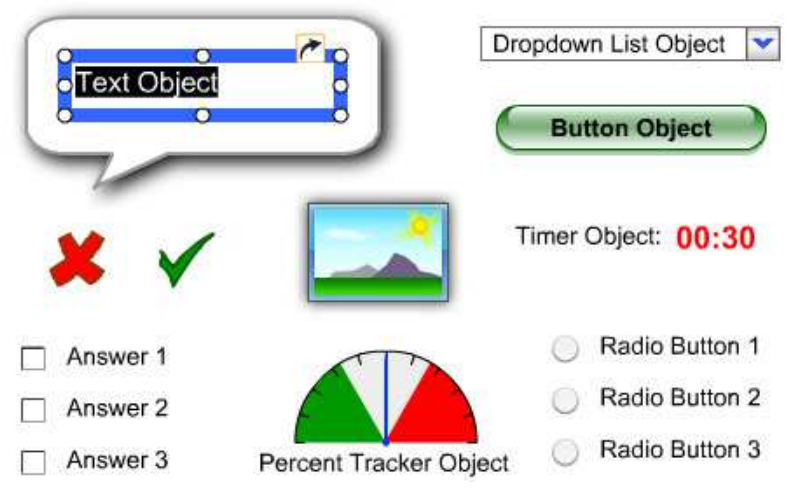

Рис. 4. Приклади об’єктів SmartBuilder 
Цей засіб дозволяє використовувати шаблони для економії часу й узгодженості дизайну. Автор може використовувати у створенні свого проекту як один з багатьох професійно побудованих шаблонів SmartBuilder, так і розробляти свої власні шаблони.

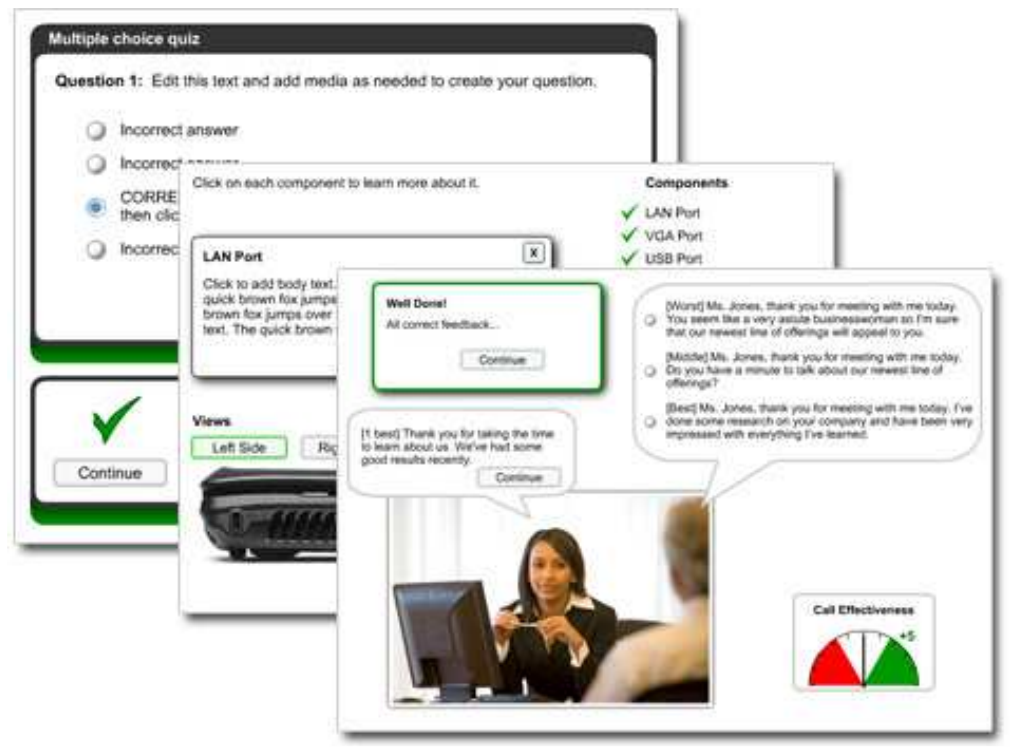

Рис. 5. Приклади шаблонів SmartBuilder

Головна сторінка сервісу SmartBuilder схожа на майстер-слайд у PowerPoint, але набагато більш потужний за своїми можливостями. Тут можна створити послідовний фон для матеріалу, що розробляється, а потім додати інтерактивні елементи, такі як меню, кнопки навігації, пошук, глосарій, допомога, регулятор гучності і т. д.

Зручним є те, що об'єкти можуть «спілкуватися» один з одним за допомогою дій. Для цього треба створити необмежену різноманітність дій, комбінуючи тригери, умови і відповіді, які можуть бути пов'язані з будь-яким об'єктом.

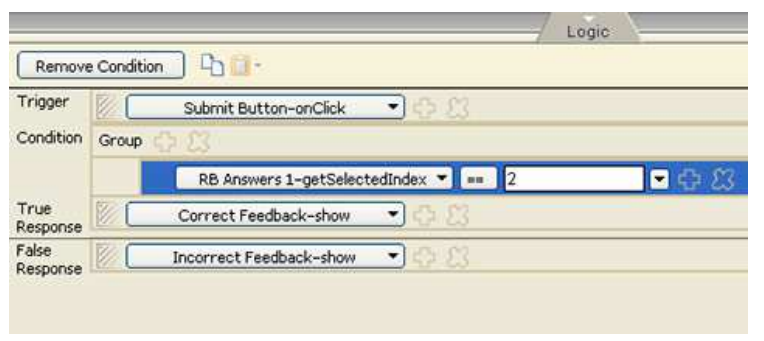

Рис. 6. Приклад використання об'єктів для «спілкування»

Сервіс дозволяє створювати посилання дії безпосередньо до об’єктів.

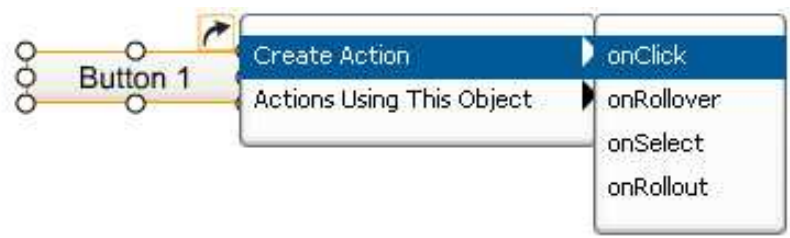

Рис. 7. Приклад створення посилання дії 
Для створення сценарію використовується спеціальний сервіс блок-схем, на основі яких можна запропонувати зрозуміле пояснення складних взаємодій.

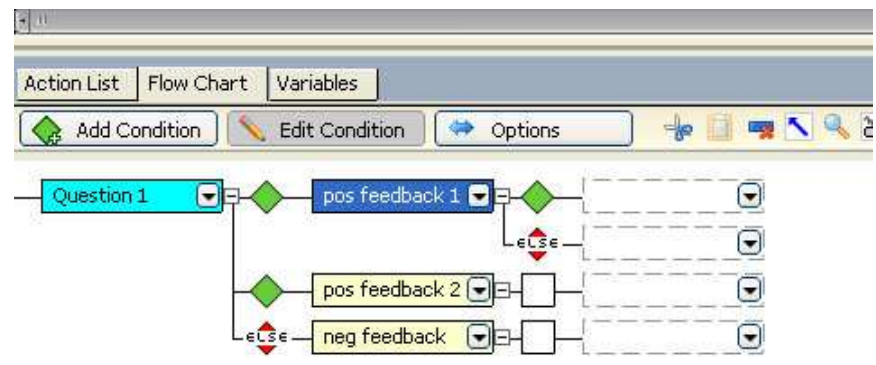

Рис. 8. Приклад використання блок-схем

Ще однією перевагою цього сервісу є наявність загальної бібліотеки. Така бібліотека дозволяє користувачам редагувати, повторно використовувати i перепрофілювати іï зміст, що, у свою чергу, дозволяє уникнути низки проблем, зокрема, конфлікту версій файлів.

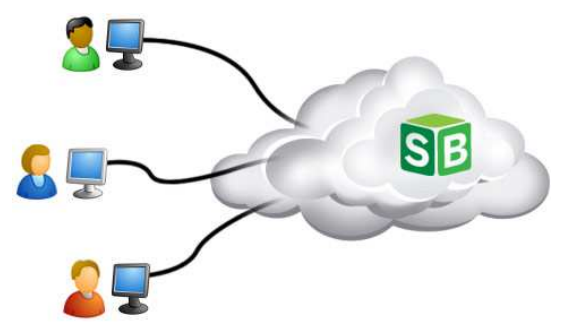

Рис. 9. Використання загальної бібліотеки

Ще один цікавий інструмент, що заслуговує уваги - WordForce $^{\mathrm{RU}}-$ інструмент для перетворення Word-документів в SCORM [7].

Ocобливості WordForce: інструмент дозволяє перетворити готові матеріали, тексти лекцій і підручники у веб-сторінки або у файли формату SCORM і картинок у веб-документ. WordForceRU - це програма для створення електронних підручників, веб-документів і сторінок, а також SCORM пакетів для електронної системи дистанційного навчання (СДН). Перетворення документів Microsoft Word у вебдокументи потрібно для виконання повсякденних робочих завдань. Можливість створювати файли у форматі SCORM незамінна для роботи з СДН. Містить вимоги до організації навчального матеріалу і всієї системи дистанційного навчання. SCORM дозволяє забезпечити сумісність компонентів i можливість їх багаторазового використання: навчальний матеріал представлений окремими невеликими блоками, які можуть включатися в різні навчальні курси i використовуватися системою дистанційного навчання незалежно від того, ким, де і за допомогою яких засобів вони були створені. SCORM заснований на стандарті XML. 


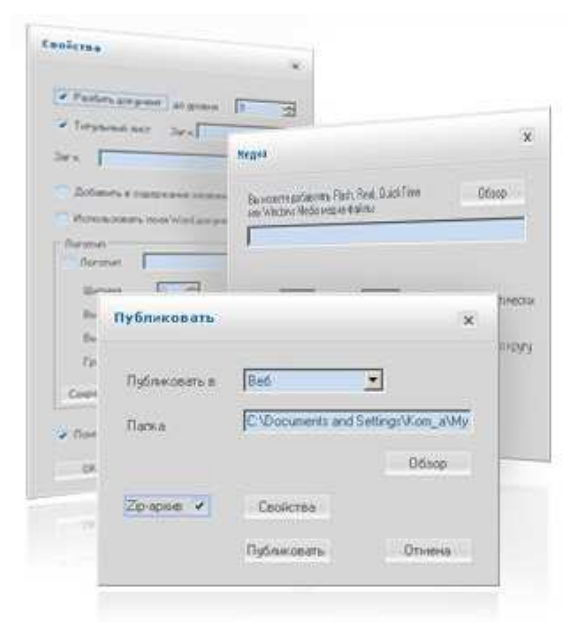

Рис. 10. Приклад інтерфейсу сервісу

У WordForce не потрібно писати скрипти для HTML сторінок, програма конвертації створить стільки сторінок, скільки потрібно. Робота з WordForce не вимагає спеціальних знань - JavaScript, HTML / CSS - потрібно лише вміти працювати 3 Microsoft Word.

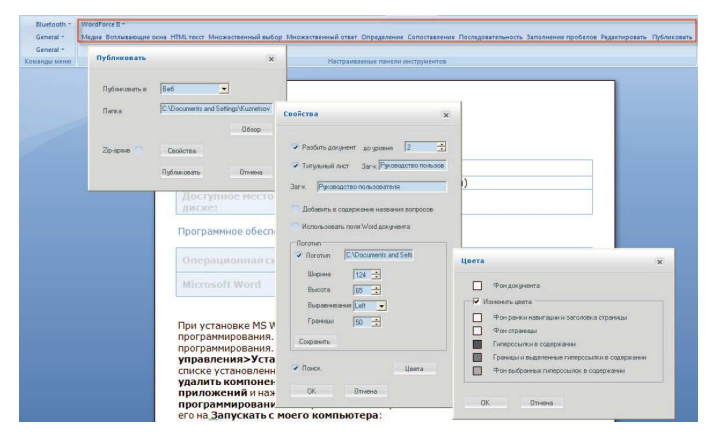

Рис. 11. Зовнішній вигляд елементів користуваџького інтерфейсу

Отже, з інструментом WordForce можсливо:

- конвертувати Word документи в електронні підручники Web i SCORM формату (далі електронний підручник);

- під час конвертації документа в електронний підручник, доповнити його тестовими завданнями (для самоконтролю);

- створювати і згодом змінювати зміст електронного підручника (за допомогою WordForce або вручну через HTML / CSS);

- попередньо переглядати створювані електронні підручники.

Стандартні дії під час створення електронного підручника включають в себе:

- додавання мультимедіа файлів, таких як Flash, відео та аудіо;

- додавання і настроювання різних елементів, включаючи спливаючі вікна;

- додавання i зміна HTML скриптів дозволяють налаштовувати роботу різних опцій, використовують HTML елементи, такі як: HTML значки, кнопки повідомлень та ін.

Характеристики WordForce:

- інтеграція з Microsoft Office (як надбудова для Microsoft Word) для зручного використання програми;

- розгорнута і коротка панель інструментів; 
- багатомовний інтерфейс.

Можливості публікаціӥ:

- публікація у Web формат (перегляд у будь-якому веб-браузері);

- публікація в SCORM (версії 1.2 / 2004), формат для використання в SCORM сумісної СДН, що автоматизує процес навігації і збору статистики;

- показ повного списку змісту Word-документа в електронному підручнику;

- швидкий перегляд і перевірка документа перед публікацією;

- показ документа у веб-браузері після публікації.

Опції електронного підручника WordForce:

- перенесення структури, налаштувань (колір, шрифт, гіперпосилання та ін.) Word документа, під час конвертації в електронний підручник;

- підтримка «деревоподібної» структури змісту (ієрархічної структури Microsoft Word документа);

- можливість пошуку;

- вибір кольорового виконання різних елементів тесту;

- можливість відповіді користувачем на питання кілька разів (під час створення тестових завдань в електронному підручнику);

- зміна зовнішнього вигляду елементів користувальницького інтерфейсу;

- налаштування колірної гами, у тому числі можливість використання корпоративних кольорів, логотипів.

Наступний сервіс для знайомства - MOS Solo [5].

MOS Cоло - простий, але функціональний інструмент, який практично не вимагає навчання, але представляє безліч можливостей у створенні мультимедійного освітнього контенту. За допомогою MOS Solo можна створювати інтерактивні електронні курси, вікторини, опитування і демонстрації [4].

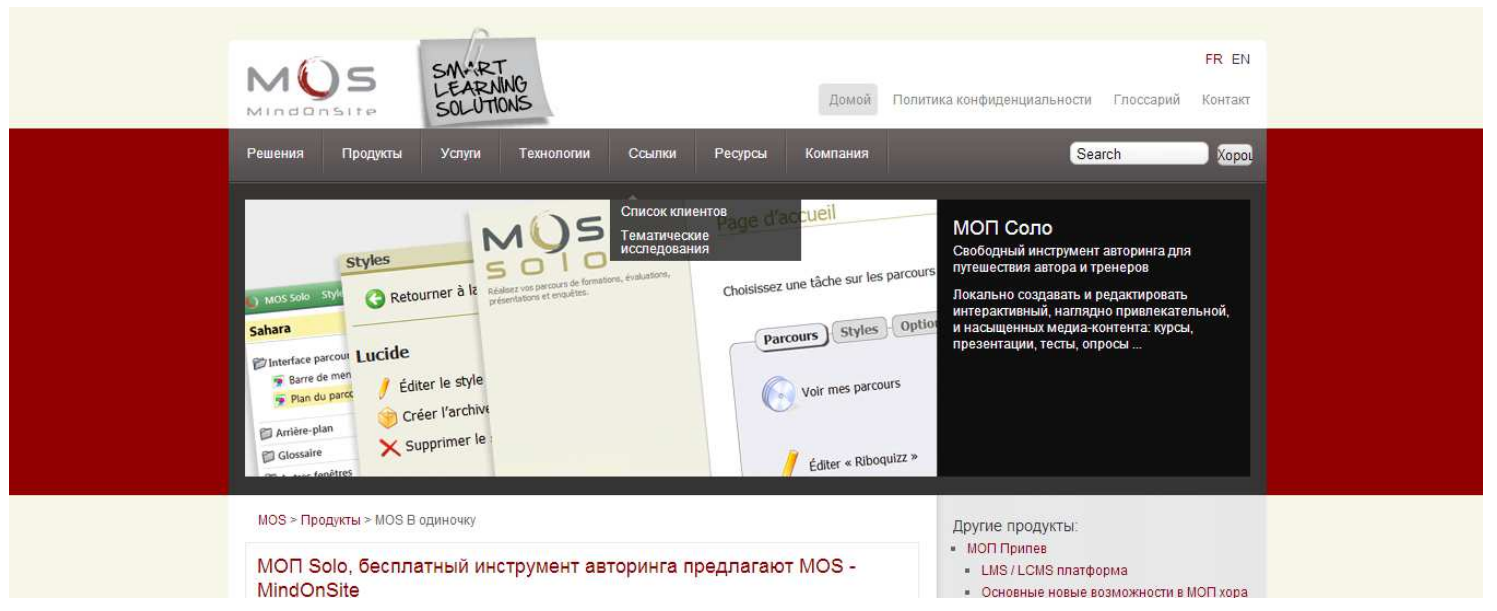

Puc. 12. Інтерфейс сервісу MOS Solo

Ocoбливості MOS Solo. Враховуючи особливості студентської аудиторії, яка користується із задоволенням різноманітними гаджетами, важливою рисою $є$ те, що цей сервіс можливо використовувати за допомогою сучасних пристроїв: популярних смартфонів і планшетів. Програмне забезпечення, створене у форматах XLM і HTML, сумісне $з$ мобільним використанням. Це може транслюватися на найпопулярніших смартфонах і планшетах: iPad, iPhone, Android, Windows. 


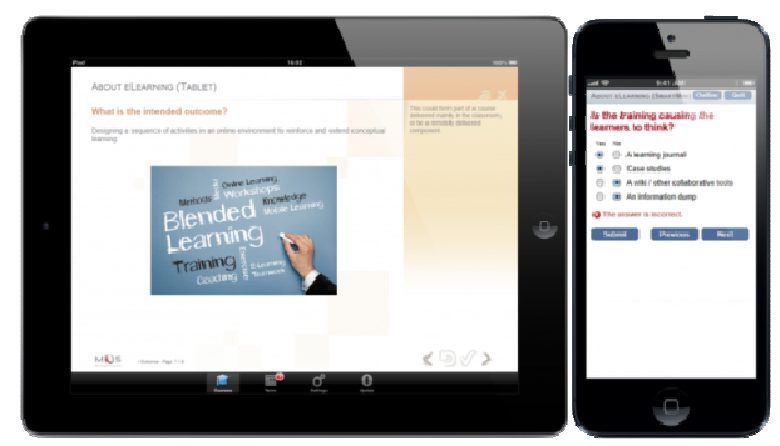

Рис. 13. Мобільне використання сервісу MOS Solo

Наступний сервіс, який може бути корисним у створенні освітнього середовища - Zenler Studio.

Zenler - це один із найпотужніших сервісів для створення освітнього контенту. За допомогою Zenler можна створювати електронні курси, які працюватимуть на різних електронних носіях, включаючи iPad, iPhone, Android. Можливе створення курсу на основі презентацій і матеріалів у PowerPoint. Сервіс також дозволяє записувати відео 3 екрану, додавати аудіо і багато іншого.

Особливості Zenler: моливість використання безкоштовної пробної версії [8].

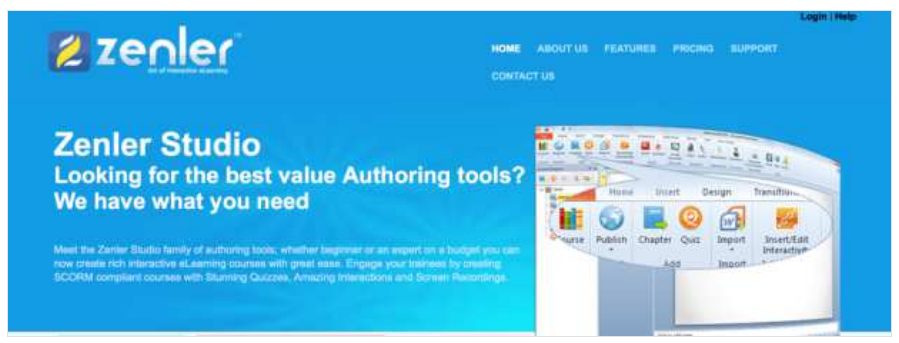

Pис. 14. Приклад інтерфейсу сервісу Zenler

Цей сервіс має розширені можливості і є системою управління навчанням (LMS). Публікація своїх Zenler-курсів он-лайн, управління, доставка матеріалів, відстеження прогресу навчання відбувається без зайвих зусиль.

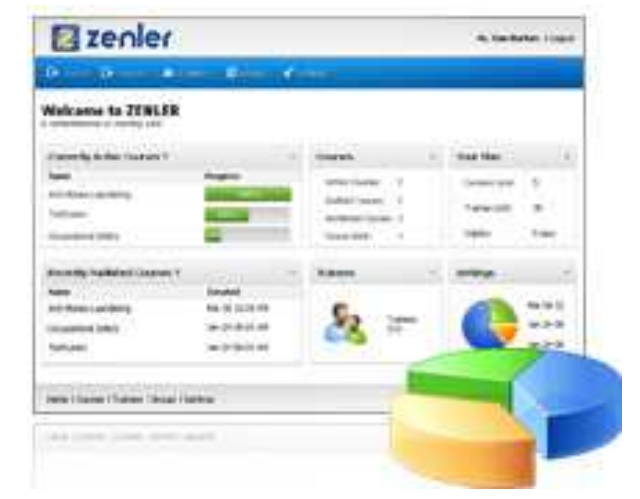

Puc. 15. Zenler - система управління навчанням 


\section{ВИСНОВКИ ТА ПЕРСПЕКТИВИ ПОДАЛЬШИХ ДОСЛІДЖЕНЬ.}

Інтерактивний характер, насиченість освітніми ресурсами, комунікативність, можливість модифікувати мету, зміст, методи й організаційні форми навчання - це дуже важливі інноваційні якості сучасних електронних засобів навчання. Від того, наскільки вдало вдається спроектувати методи і прийоми навчання у використанні сучасних засобів, залежить результат самого навчання, особливо, коли мова йдеться про створення спеціального навчального середовища і використання його в процесі адаптації іноземних студентів. Безумовно, запропоновані інструменти залишаються відкритим списком можливостей створення такого середовища. Розглянуті ресурси підкреслюють вдале поєднання потужних інструментів і простоти їх використання для створення інтерактивних навчальних матеріалів. Застосування спеціальних засобів візуалізації, створення та використання словників, демонстрація процесів, ретельно продумане залучення мультимедійних, навігаційних та інших засобів, що пропонують інформаційні технології, допоможуть адаптувати матеріал і перетворити його в ефективний засіб навчання.

\section{СПИСОК ВИКОРИСТАНИХ ДЖЕРЕЛ}

1. Барбер М. Открытая лекция на тему «Как хорошие образовательные системы могут стать еще лучше?» [Електронний ресурс]. http://www.hse.ru/data/2010/05/26/1216917185/barber.pdf.

2. Биков В. Ю. Моделі організаційних систем відкритої освіти : монографія. — К. : Атіка, 2009. — $684 \mathrm{c}$.

3. Лаптєва М. В. Використання електронної підтримки на адаптаційному етапі навчання іноземних студентів у педагогічному внз України // Інформаційні технології в освіт i: матер. VI Всеукраїнської наук-практ конф. - Мелітополь : Вид-во МДПУ ім. Б. Хмельницького, 2014. — С. 169-174.

4. Офіційний сайт CourseLab [Електронний ресурс]. - Режим доступу : http://labmedia.su/portfolio/38.

5. Офіційний сайт MOS Solo [Електронний ресурс]. - Режим доступу : http://www.mindonsite.com/en/produits/mos-solo.

6. Офіційний сайт Smart Builder [Електронний ресурс]. - Режим доступу : http://www.smartbuilder.com.

7. Офіційний сайт WordForce ${ }^{\mathrm{RU}}$ [Електронний ресурc]. - Режим доступу : http://www.joomlalms.com.

8. Офіційний сайт Zenler [Електронний ресурс]. — Режим доступу : http://www.zenler.com.

Матеріал надійшов до редакиії 31.10.2014 p.

\section{ИНСТРУМЕНТЫ СОЗДАНИЯ СПЕЦИАЛИЗИРОВАННОЙ ОБРАЗОВАТЕЛЬНОЙ СРЕДЫ ДЛЯ ОБУЧЕНИЯ ИНОСТРАННЫХ СТУДЕНТОВ В ПЕДАГОГИЧЕСКИХ ВУЗАХ УКРАИНЫ}

\footnotetext{
Лаптева Мария Викторовна

кандидат педагогических наук, докторант кафедры теории и методики профессионального образования Харьковский национальный педагогический университет имени Г. С. Сковороды, г. Харьков, Украина mlapteva@ukr.net
}

Аннотация. В статье сделан анализ инструментария для создания современной образовательной среды для адаптации иностранных студентов в учебном процессе в высших педагогических учебных заведениях Украины. Рассмотрены возможности использования различных сервисов в практической деятельности преподавателя для построения образовательного пространства с учетом специфики учебной аудитории. 
Проанализированы особенности обучения иностранной аудитории. Предложен ряд свободных в использовании сервисов, которые удачно сочетают мощные и простые в использовании средства для создания интерактивных учебных материалов, предназначенных для применения в сети Интернет в системах дистанционного обучения или другом носителе.

Ключевые слова: образовательная среда; интерактивные учебные материалы; иностранные студенты.

\title{
CREATION TOOLS OF SPECIALIZED EDUCATIONAL ENVIRONMENT FOR FOREIGN STUDENTS TRAINING IN PEDAGOGICAL HIGHER ESTABLISHMENTS OF UKRAINE
}

\author{
Mariia V. Laptieva \\ $\mathrm{PhD}$ (pedagogical sciences), doctoral student in the theory and methodology of professional education \\ H. S. Skovoroda Kharkiv National Pedagogical University, Kharkiv, Ukraine. \\ mlapteva@ukr.net
}

\begin{abstract}
In the article it is analyzed the tools for creation of a modern educational environment for the adaptation of foreign students in the learning process in pedagogical higher establishments of Ukraine. The possibilities of using of various services in the practice of the teacher to build educational space with access to the cooperative activities of students taking into account learners specificity are considered. It is analyzed features of foreign students learning. There are proposed free-to-use services that successfully combine powerful and easy-to-use tools for creation of interactive learning materials in the Internet, distance learning systems, or other media.
\end{abstract}

Keywords: learning environment; interactive learning materials; foreign students.

\section{REFERENCES (TRANSLATED AND TRANSLITERATED)}

1. M. Barber. Open lecture on "How the good educational system can become even better?" May 22, 2010. — [online]. — Available from: http://www.hse.ru/data/2010/05/26/1216917185/barber.pdf (in Russian).

2. V. Bykov. Models of organizational systems for open education. - K. : Atika, 2009. — 684 p. (in Ukrainian).

3. M. Laptyeva. Using E-support for adaptive stage of training foreign students in pedagogical high schools of Ukraine // Information Technology in Education: VI All-Ukrainian science and practical conference. - Melitopol, 2014. — P. 169-174 (in Ukrainian).

4. Official Website CourseLab [online]. - Available from : http://labmedia.su/portfolio/38 (in Russian).

5. Official Website MOS Solo [online]. — Available from : http://www.mindonsite.com/en/produits/mossolo (in English).

6. Official Website Smart Builder [online]. - Available from : http://www.smartbuilder.com (in English).

7. Official Website WordForce ${ }^{\mathrm{RU}}$ [online]. — Available from : http://www.joomlalms.com/rapid-authoringtools/wordforce.html (in English).

8. Official Website Zenler [online]. - Available from : http://www.zenler.com (in English). 